\title{
The Basic Meaning of the Tithe Based on the Holy Bible
}

\author{
Liyus Waruwu \\ IAKN Tarutung \\ liyuswaruwu@yahoo.co.id
}

\begin{abstract}
The purpose of the research was to reveal the meaning of the tenths (tithe) from Abraham as the symbol of his obedience to his God. since the research belongs to qualitative research by literature study approach (searching throughout the content of the Holy Bible), so that the data is gathered by using heurmeunetics method. Data display was administered after digging and searching all the scriptures corcerning about. As the result, it was found that motivation of Abraham to give offerings to MelchizedeK, the king of Sodom together with other kings were rebelling out towards Chedorlaomer the king of Elam. Finally, the king of Salem Melchisedech brought forth bread and wine, he tried to bring him a new renewal life "Blessed be Abraham of the most high God, the owner of heaven and earth; and blessed be the most high God, and his name was changed from Abram to Abraham.
\end{abstract}

Keywords: The Tithe offering, rebelling out, defeated the enemy

\section{Introduction}

This study belongs to qualitative research using literatur/library approach in gathering the data, namely secondary data throughout various books and HB is the main resources of the data. The problem of the research regarding about the research question, how comes the term of the tenths (identicaly with tithe) being a kind of dogma in Cristianity and becomes a compulsory for all Christian. The purpose of the study was to find out the reason of how comes the term of the tents and being a compulsory as a dogma/doctrine for Christian around the world.

Since the study was qualitative research of which data display resourcing from the literature and HB is the main data and the researcher was a key informant. Data gathering was done by consulting the problem of the research to various books and conversed to the truth that has been written in the HB besides explaining by the writer knowledge as he is a Priest and a doctor of theology.

Data display was taken by reduction technique which means that every data concerning about the problem was consulting and proving to more than one text and sometimes more than one books in the Holy Bible (HB). Furthermore, the scripture as the key point to the problem was taken as bolded text to answer the question of the research. That is the reason that theological research usually contains many scripture by scripture, verse by verse from various books in the HB to prove the same context or case but different content to represent the same solution of the research problem. In such a data analysis, it is usually to present the writer's interpretation dealing with all the gathered data and finally closing by summarizing in his own literacy to bring the idea and solution for the readers. Findings of the study that derived from the result of the data analysis was a part of the conclusion which emphasized for the readers to 
implicate in daily life, and finally from such a fact in the findings the writer settled a line of significances of the research result for human life especially for Christian.

\section{Methods}

Research methodology used was Holy Bible observation \& interpretation since it could not found the information about logical reason of numeric use in that context therefore, it needs literature study to dig the information concerning precise history, culture and the condition of Israel faith and environment at the decade. To define the context and history, there were 6 general interpretation types and 3 specific interpretation types but all are contextual oriented. It is hopefully that throughout this study the circumstances above can be synthesized so as to enrich theology treasury.

The study conducting qualitative research by using bilical-conversion approach which belongs to literature research of which data is resoucing from documentation then having reduction based on the HB content and context. In this case, the writer researching each of the scripture that concerning to the obtained data after consulting with other related books as well as hermeneutic chain. Practically, the aqpproach using theology- exegesis consult namely presenting the truth as in Genesis 14 based on the original language, Hebrew for old tesstsment and by presenting some hermeneutical questions following by interpretation based on: context, history, theology, purpose of writing, grammatical and meaning. Understanding a scripture should be consult to the context implide in the scripture itself because if there is any interpretation out of context, the resut is that the message can be biased and even becomes meaningless. In this study, there is not any interpretation without context.

\section{Research Result and Discussion}

The term of the tenths has been derived from the Holy Bible (HB) in Genesis 14:20 of which Abraham had an idea to give offerings to Melchizedek in the form of naration when King Chedorlaomer and his friends defeated the king of Sodom and other kings around. At the event, Lot the nephew of Abraham was captivated, and it made Abraham became angry therefore he gathered and led his power to defeat his enemies. His excellence to defeat other winner kings made him being wellknown by most of the people.

As a return for his winner, then he was welcomed by 2 guests, they were Melchizedek and the king of Sodom and they brought someting as a gift for him upon his winning bettle. Abraham responded cheerfully against Melchizedek the man who ever blessed him and then he actualized it by thanks-giving namely the tenths or it is similar with $10 \%$ from all his earning. This is the expression of Abraham from the bottom of his heart and even prior to his meeting with Melchizedek he has had good feeling out and at the time they met he was so fruitfull and bowing against Melchizedek. This context made him expressively giving his thanks-giving in the form of the tenths to Melchizedek, the man with no parents. Kline (2012) interpret that the tenths from Abraham to Melchizedek is a means of obeying and bowing to Yahweh, for him that Melchizedek equals to Yahweh based on his belief since He was the only person who ever blessed Abraham, the interpretation bolded here is that whatever the kingdom who dominates Canaan, Truely to say that Yahweh is the only king who owns every thing. Belief in Abraham era and now on is so long around 3500 years that is why there are 
many gaps happened such as : contextual gap and historical gap, it needs a deep analysis to prescribe the context of each history proportionally and also to brigdge both of the contexts to prove the truth. It is reasonable to analize what background is motivated Abraham to act in such expressive obadience and bow towards Melchizedek that he believed eqals to Yahweh.

Abraham who was well known as Abram before, is known as a main fugure in the HB, he was a delighted person and admired by hebrew/ Jewish people, those who believe in Jesus and even the moslem did. It is not only by his personal as the phisical and faith ancestor for the three religions but also his easy-going thinking for the sake of goodness which was not logical for human but he could run well especially about the first tenths that ever happened and supported by other book writers in the HB.

Based on the HB (Genesis 5: 1-32), Abraham was the 20th descent from the first human being, the following is the order line: Adam to set, Set to his son-Enos, Enos to his son-Kenan, Kenan to Mahalael, Mahalalael to Yared, Yared to his son-Henoch, Henokh to Metusalah, Metusalah to Lamekh, Lamekh to his son-Noah, Noah to his son-Sem, Sem to Arpakhsad, Apakhsad to Selah, Selah to Selah, Eber to Peleg son-Peleg, Peleg to his son-Rehu, Rehu to Serug, Serug to Nahor, Nahor to Terah, Terah to his son-Abram whose name was changed to become Abraham. Some of them gave their thanks-giving in the form of farming harvest. So, the first human who gave thanks-giving to God in the form of the tenths, was Abraham throughout the honorable king, Melchizedekh who were confessed as God's Pastor. After Abraham obeyed God's words to leave his father's house to a secret place that only God knows, and also doing God's challange for him to dedicate his son, doing circumcision, and so forth to show his obedeance for God. In Hebrew language the tenths is written as the

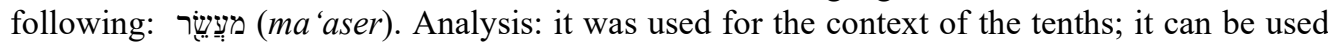
for either secular or sacral context; it can be actualized as tax given to the king, probably existed in town or village, if it is in village, the form could be harvest, or sheep.

The action of Abraham to give his tenths is a perfect action, Septuagint with the translation using the Greek word: $\check{\varepsilon} \delta \omega \kappa \varepsilon v$ indicative verb, 3rd person singular from $\delta i \delta \omega \mu$. From grammatical side, indicative verb can be define that Abraham gave a tenth of his harvest to Melchisedekh as his thanks-giving, that is the core, it is not talking about what is given and how to give, that is not the problem. The other word that is similar with the tenths is ('esroim). Literally, giving the tenths means to donate a tenth from what he owns. The word

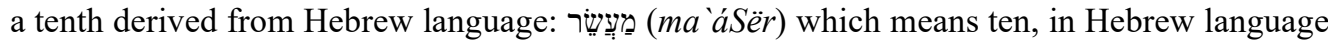

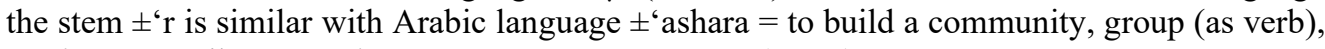

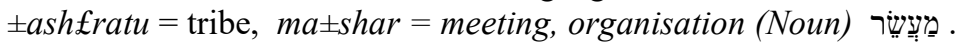

In TWOT v.9. Electronic. Ed). The interpretation of the tenths semantically rooting from human's finger are 10 which united in a unity or collection, thetrefore, in Arabian language it is $\pm a s h r u$, in Ugarit is $\pm p r$, in Akkadia is epru, and in the bible of Aram is $\pm^{\prime}$ ar'. Abraham action can not be under-estimated (verse: 20) since it was happened whilst in the war (verse : 1-19).

Contextual interpretation; it consists of words, phrases, and paragraph which is dependable one each other, even when it is saparated then the result is meaningless. To find the contextual meaning of the texts in $\mathrm{HB}$, the text before and after the text reading on, should be engaged and tied unitedly. There are 2 kinds of contextual interpretation; short contextual interpretation and long contextual interpretation, see Stuart (2004). Short contextual interpretation is only 2 or 3 paragraphs after and before the eying text to be angaged in analysis. Whereas, long contextual is all the text covered in one book of the HB, should be read at once as a unity to interprete the meaning. As an addition to be a part of interpretation strategy, the interpreter can 
also interprete a context by consulting across some books wich containing the same topic or theme.

On the other hand, the writer also used etymology approach in interpreting the context of the problem question of the research, by consulting the term of the tenths (verse;20) towards Levi language, of which Levian has a system of the tenths. In this case, the purpose of the last verse: 20 is to claim a legacy for all people of giving the tenths personally, in this context, Abraham presented his thenths (from his earn) for the pastor who was received as God's prolonged hands, see (Westernman, 2006).

This story is also correlated to Israel culture, see Anderson $(2009 ; 84)$, the tenths for God or for government is good enough in this nationality to figure out the nation's obediance to the Creator of the universe, and to the leader of the nation, as well. Melchizedekh was wellknown as the king and the pastor in the country, see (verse : 18), in the name of God, he welcomed Abraham with all his soldiers who brough a big victory from the war, and that was the reason for Abraham expressively responded him by thanks-giving that actualized in the tenths. This context figured out the nation circumstance that Pastor who prays for people is higherhonorable than a king, it was also a part of a myth they had.

As the same response, Melchizedekh spontanously welcomed Abraham and his soldiers was to appreciate all his effors to defeated his enemies though his victory is out of thought since the condition of the war was so unlogical for him to win. The king had a reason to trust him as a blesed man in the victoy, so that it was reasonable for Melchizedekh him as welcoming him as a symbol of God's blessess. The following is the analysis of God's blesses for Abraham in his strugle to defeat the enemy; a technique of a war, if enemy is nearly besieged by rival, thing to do is only give up, and empty the body from the weapons while lifting two hands up as to simbolize the giving-up. Further more, to give up should be totally without obscurity, hands up with fingers upper stright. So did Abraham knew about it and he did the same towards Melchizedekh, the honorable God's hands prolength. Abraham was inspirated from what he has done for such a tenths, to proceed it as habitual activity to thanks God, and even other people have taken it as a good manner to glorify God by giving $10 \%$ of their earning to God's church monthly. In modern era, salary is a standard to bold one's tenths per month, which means that $10 \%$ from the salary is a compulsory to give for God throughout the church. For instance, if the salary IDR. $10.000 .000^{\circ}-$, so the tenths that should be given to God is IDR. 1.000.000,-.

According to Anderson that Abraham action to actualize his thanks-giving in the tenths to Melchizedekh is so reasonable : Melchizedekh was a king; he has given him foods and drinks, and blessed him; Melchizedekh position as a leader and honorable Pastor; things that was donated only $10 \%$ from harvest, and the harvest in the context was all from booty (jarahan). In Genesis 14:20 the tenths from Abraham is a voluntary, hearted giving, it is not a force as stated in Genessis 1 Sem 8:15-17. And then it is supported by the scipture in 1 Sam. 8 that the tenths of Abraham is an ideal action, so that he did it fairly without any forcing feeling in what so ever condition.

Implication of Abraham's tenths at this latest era, which has been started from the oldest era, see (Genesis 14:20), the scripture says that the ivent was not only an abstract/fictive story/characters, but it was really happened and texted in the Holy Bible. And even, before the term of the tenths has been arisen, thanks-giving was actually done before but the name of the action was not the tenths, it was only known as thanks-giving for God. Melchizedekk as the highest pastor was wellknown as the king of Salem and the most honorable pastor, of which all the kings around were obedient to him. According to the writer assumption throughout 
some readable resources that Salem is similar with Jerusalem, and it probably means ,'peace', so that king Salem means king of peace.

Interpreting about Abraham phisically, the writer can claim that he is a very healthy man, see (Genesis 14:1-20) the condition is about a war among various nations, and he is an expert in war, his phisic was normal enough and it s proved by the words that he had 10 fingers up as the reason of derived term the tenths. The term that has been arisen not the sevenths, nor the nineths but the tenths because he finggers up by ten not by nine.

That is a devine/Godlike secret that is rarely to expose that Abraham gave his tenths as a symbol of obedience towards God's authority upon the universe and the sky, the symbol of hearted will to believe totally in God so that he focused to take the challange from God to leave his home and his siblings, leaving his own country going to other vague country, obeying about circumcision, and dedicating his son for God's challange, see (Gen. 12-22). Other scriptures that support Abraham as an obedient man is about Sarfat, a widow that he saved from hunger when he firstly gave a hand of flour and a little oil to cook for once lunch together with her son, based on God's instruction by Elia, see (1 Kings 17:7-24) and many others same tone scriptures that support his obedient character.

\section{Conclusion}

Actualizing thanks-giving by the tenths in some books, scripture by scripture in HB, but the one in Genesis 14 is the oldest scripture to tell about. Contextual narration in verses 1-20 figuring out the war condition among the nations, henceforth, Lot the nephew of Abraham was captured around Sodom city. He was fighting against 318 enemies and finally he defeated them. He returned bringing a victory, and one of the King who welcomed him was Melchizedek who was also the highest honorable pastor in the country, the King of Salem.

From grammatical side, indicative verb can be define that Abraham gave a tenth of his harvest to Melchisedekh as his thanks-giving, that is the core, it is not talking about what is given and how to give, that is not the core of discussion. Abraham's action to actualize his tenths showing that human being is weak, or doesn't have any sense without God, He is the creator of everything, and belongs to him. So, the first human who gave thanks-giving to God in the form of the tenths, was Abraham throughout the honorable king, Melchizedekh who were confessed as God's Pastor. After Abraham obeyed God's words to leave his father's house to a secret place that only God knows, and also doing God's challange for him to dedicate his son, doing circumcision, and so forth to show his obedeance for God.

Abraham's victory from the war was not as a return of his smartness or his power, but because of his faith. Everybody can be truly supported because of the faith, the tenths from Abraham to Melchizedek is a means of obeying and bowing to Yahweh, for him that Melchizedek equals to Yahweh based on his belief since He was the only person who ever blessed Abraham. 


\section{Reference}

[1] Averbeck, Richard E., The New International Dictionary of Old Testament Theology and Exegesis (Grand Rapids: Zondervan Publishing House).

[2] Baker, David L., John J. Bimson, Mari Mengenal Arkeologi Alkitab (Jakarta: PT BPK Gunung Mulia, 2009).

[3] Cheek \& Rooney. 2015. Charity and Philanthropy Retrieved from https://www.sciencedirect.com/topics/social-sciences/caritas. by May 2020

[4] Deursen, A. Van, Purbakala Alkitab dalam Kata dan Gambar (Jakarta: PT BPK Gunung Mulia, 2000)

[5] Fee, Gordon D. dan Douglas Stuart, Hermeneutik, Bagaimana Menafsirkan Firman Tuhan Dengan Tepat! (Malang: Gandum Mas, 1989)

[6] Harefa, Etiknius, Konstruksi Penelitian Teologi (Medan: Prodi Teologi STTSU, 2015).

[7] Longman III, Tremper, Panorama Kejadian Awal Mula Sejarah (Jakarta: --, 2013)

[8] Jenkins, Simon, Peta Alkitab Pen. H.A. Oppusunggu (Jakarta: Yayasan Komunikasi Bina Kasih/OMF, --).

[9] Kaiser, Walter C. Jr. Ucapan Yang Sulit Dalam Perjanjian Lama. (Malang: Seminari Alkitab Asia Tenggara, 1999)

[10] LaSor, W.S., D.A. Hubbard dan W.S. Bush, Pengantar Perjanjian Lama (Jakarta: BPK Gunung Mulia, 2004)

[11] McKinley. 2019. What Is a Tithe? Meaning and Importance of Thiting in the Bible. Retrieved from: https://www.christianity.com/wiki/christian-life/what-is-a-tithe-meaning-and-importanceof-tithing-in-the-bible.html. By May 2020

[12] Nicodem. 2020. About Tithing. Retrieved from: https://ccclife.org/tithing/ by May 2020.

[13] Osborne, Grant R., Spiral Hermeneutika Pengantar Komprehensif bagi Penafsiran Alkitab (Surabaya: Momentum, 2012)

[14] Pariera, Berthold A., Abraham Imigran Tuhan dan Bapak Bangsa-bangsa (Malang: Dioma, 2006)

[15] Park, Abraham, Silsilah Kitab Kejadian Dilihat dari Sudut Pandang Sejarah Penebusan (Jakarta: Grasindo, 2010).

[16] Rowley, H.H., Ibadat Israel Kuno Pen. I.J. Cairns (Jakarta: PT BPK Gunung Mulia, 2009).

[17] Snell, Daniel C., Kehidupan di Timur Tengah Kuno 3100-332 SM (Jakarta: BPK Gunung Mulia, 2012) 